\title{
Optimum Percentage of Sawdust and Brick Ballast in Light Weight Concrete
}

\author{
Neeru Singla ${ }^{1}$, Mandeep Kumar ${ }^{2}$ \\ ${ }^{12}$ IGKPTU, Jalandhar, Punjab, India. \\ E-mail: neeru_024@yahoo.com \\ Published Online: 28 December, 2017
}

The Author(s) 2017. This article is published with open access at www.chitkara.edu.in/publications
Abstract: Construction industry relies heavily on conventional material such as cement, sand and gravel for the production of concrete The river sand and gravels which are most commonly used as fine aggregates and coarse aggregates respectively in the production of concrete, poses the problem of acute shortage in many areas, whose continued use has started posing serious problem with respect to its availability, cost and environmental impact. Attempt is being made in this project to use the locally available waste materials to replace the river sand and gravels to produce light weight and low cost concrete. Sawdust and Brick ballast are easily affordable at low costs, which are partially replaces with river sand and gravels respectively for making concrete. Natural sand and Gravels have been partially replaced (4\% SD $8 \%$ BB, $4 \%$ SD $16 \%$ BB, $4 \%$ SD $24 \%$ BB, $8 \%$ SD $8 \%$ BB, $8 \%$ SD $16 \%$ BB, $8 \%$ SD $24 \%$ BB, $12 \%$ SD $8 \%$ BB, $12 \%$ SD $16 \%$ BB and $12 \%$ SD $24 \%$ BB. by using M30 grade of concrete) with sawdust and broken brick ballast respectively. For this, thirty concrete cubes of size $150 \mathrm{~mm} \mathrm{X} 150 \mathrm{~mm}$ $\mathrm{X} 150 \mathrm{~mm}$ have been casted and water cement ratio of 0.42 has been used. Water reducing admixture is used to increase the workability. Slump test, Compacting factor test and compressive strength at (28 days) of specimens having above combinations have been compared with control specimens. The workability and compressive strength gradually decreases for the increasing the replacement percentages. The optimum mix found to produce M30 grade of concrete is $8 \%$ of sawdust and $16 \%$ of Brick ballast

\section{INTRODUCTION}

As the time is passing, due to the development of infrastructure the construction industry is growing at a vast rate. Concrete is a mixture of cement, fine aggregates, coarse aggregates and water. Normally river sand is used as fine aggregates and stones or gravels are used as coarse aggregates in the concrete. These materials are limited on the earth. To overcome this type of problem researcher found substitute materials for aggregates. There are many types of waste materials available in our environment, which can be replaced with aggregates in concrete for making concrete. These waste light weight materials
Journal on Today's Ideas Tomorrow's Technologies, Vol. 5, No. 2, December 2017 pp. $112-122$

CHITKARA 司 UNIVERSITY 
are sawdust, fly ash, Rice husk ash, cow dung and over burnt bricks etc. If these materials are directly disposed in our environment then it causes many problems. So these materials can be used as construction material for making concrete. The choice of these substitute materials depends upon availability; cost factor, physical and chemical composition of ingredients. Saw dust and brick ballast are the waste materials which can be replaced with fine aggregate and coarse aggregate respectively in concrete. Sawdust can be defined as loose particles or wood chippings attained as by products from sawing of timber into standard useable sizes. Sawdust is often dumped as waste products and about 105 million tonnes of sawdust are generated annually in India alone. The sawdust is light in weight as compare to river sand. During manufacturing of bricks in a kiln, high amount of over burnt bricks are produced which acts as a waste. These bricks can be recycled by using with replacement of coarse aggregates in concrete. The major volume of ingredients in concrete is the aggregates, it attains $60-80 \%$ of the total volume of concrete. So that the cost of the whole concrete is largely depends upon the aggregates used Both these materials are light in weight, so that it is helpful to construct light weight structures These studies try to match social need for safe and economic disposal of waste materials with the help of environmental friendly industries, which need better and cost-effective construction materials.

\section{LITERATURE REVIEW}

K. Ambiga and P. Meenakshi (2015) have studied on low cost waste construction material as saw dust in production of concrete cubes to investigate the best possible solutions.. They casted the three specimen for curing period of 7 days and 28 days by partial replacement of sand with sawdust with a varying proportion of $10 \%, 20 \%, 30 \%$.

Saurabh G. Sable and S. B. Walke (2015) researched on partial replacement for stone aggregate with brick ballast in concrete. This research should provide optimum replacement of $30 \%$ brick aggregate replaced for natural coarse aggregate was found feasible and economical.

P. Sri Chandana and Shaik Ahamed Mvouddin (2015) have studied on the effect of replacement of fine aggregates with sawdust and robosand in concrete mixture for building construction. The optimum mix found to produce M20 grade of concrete is $10 \%$ of sawdust and $40 \%$ of robosand, totally $50 \%$ replacement of river sand. The weight reduction achieved was $7 \%$ and cost reduction was $2 \%$ per cubic meter of concrete.

K. Gopinath et al. (2015) researched on the low cost construction material for concrete and mortar as sawdust and investigated on various concrete and mortar properties in plastic and hardened stage such as Slump test, compacting
Optimum

Percentage of

Sawdust and

Brick Ballast in

Light Weight

Concrete

$\longrightarrow$


Singla, N.

Kumar, M.

factor test, weight analysis, compressive strength and cost analysis. In present paper, the researchers introduced two reproductive form of sawdust such as Dry sawdust and Sawdust Ash. Dry sawdust was partially replaced for fine aggregates and sawdust ash was used for partially replacement for cement. They were casted 16 mortar cubes and 48 concrete cubes for curing period of 7 days and 28 days. For 1:5 mortar, Compressive strength of sawdust mortar cube after 7 days of curing achieve $92 \%, 77 \%$ and $50 \%$ of strength for $10 \%$, $30 \%$ and $50 \%$ respectively and self weight decreases $5 \%, 10 \%$ and $17 \%$ for $10 \%, 30 \%$ and $50 \%$ respectively. For M20 grade of concrete, design mix ratio of 1:1.5:3, Compressive strength of Dry sawdust concrete after 28 days curing was achieved $80 \%, 75 \%$ and $47 \%$ of strength for $10 \%, 30 \%$ and $50 \%$ replacement of Dry sawdust for fine aggregate respectively.

Mahmud Abubakar et al. (2013) researched on the use of sawdust as partial replacement for the fine aggregates in concrete production. Sawdust was used to replace fine aggregates from $0 \%$ to $50 \%$ in steps of $10 \%$. Concrete cubes measuring $150 \times 150 \times 150 \mathrm{~mm}$ were casted and their compressive strengths evaluated at 7, 14, 21 and 28 days. From the results, the optimum sawdust content was obtained at $10 \%$ and its corresponding compressive strength at 28 days is $7.41 \mathrm{~N} / \mathrm{sq}$. mm which falls within the characteristics strength of plain concrete $(7-10 \mathrm{~N} / \mathrm{sq} . \mathrm{mm})$. This concrete cannot be used in structural applications.

Prof. R. Sathish Kumar (2012) has studied on the properties of concrete varied with the use of alternate construction material in concrete. He used cement, sand, rice husk ash, coarse aggregate, sawdust, brick bats, recycled aggregates as materials in concrete. The compressive strength of concrete made with sawdust was found to be nearly $10-15 \%$ of normal concrete. The maximum average compressive strength of sawdust concrete after 7 days and 28 days is $20.26 \mathrm{Kg} / \mathrm{sq}$. $\mathrm{Cm}$ and $43.22 \mathrm{Kg} / \mathrm{sq}$. cm at proportion of 1:(1+0.5):3 and water-cement ratio of 0.75 .

M. Mageswari and B. Vidivelli (2009) researched on the usage of waste sawdust ash, which are generated from rice mills replaced with fine aggregates in concrete and conserved the natural resources. The natural sand was partially replaced with sawdust ash at different proportion such as $5 \%, 10 \%, 15 \%, 20 \%$, $25 \%$ and $30 \%$. The optimum result for compressive strength of concrete made with sawdust concrete was found in between $10-20 \%$ (by weight) of normal concrete.

\section{METHODOLOGY}

The test specimens have been casted using cement (PPC), Sand, Sawdust (having moisture content 9.8\%), Gravel, Brick Ballast (having moisture 
content $13.5 \%$ ) and water. The materials, in general, confirming to the specifications laid down in the relevant Indian Standard Codes of Practice, wherever applicable. Super plasticizer (ROFF 820 super Plast) based on high molecular weight polymers and sulphonated melamine formaldehyde has been used throughout the investigation. The nominal dose of the super plasticizer has been kept at $1.0 \%$ of the weight of cement. Sawdust and Brick Ballast are partially replaces with sand and gravels and different percentage.

The proportion by weight of the ingredients constituting the concrete mix is $1: 1.23: 2.53$ with a water-cement ratio of 0.42 by weight. A total of 30 no. of cubes have been casted and tested after 28 days. Detail of test specimens is given in table 1.The standard size of cube $150 \mathrm{~mm} \times 150 \mathrm{~mm} \times$ $150 \mathrm{~mm}$ is used. The casting of the various specimens has been done under laboratory conditions using standard equipments. Each casting batch consists of at least three cubes determining the concrete cube compressive strength. The compressive test was conducted using a $2000 \mathrm{KN}$ capacity compression testing machine.

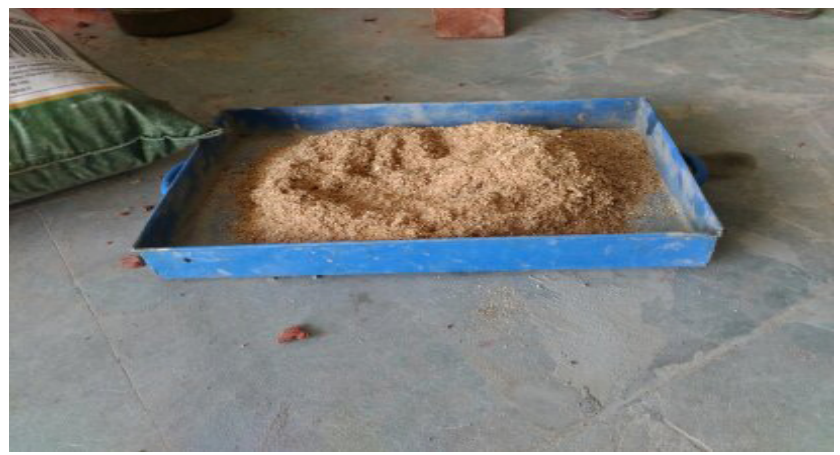

Fig. 1: Saw Dust

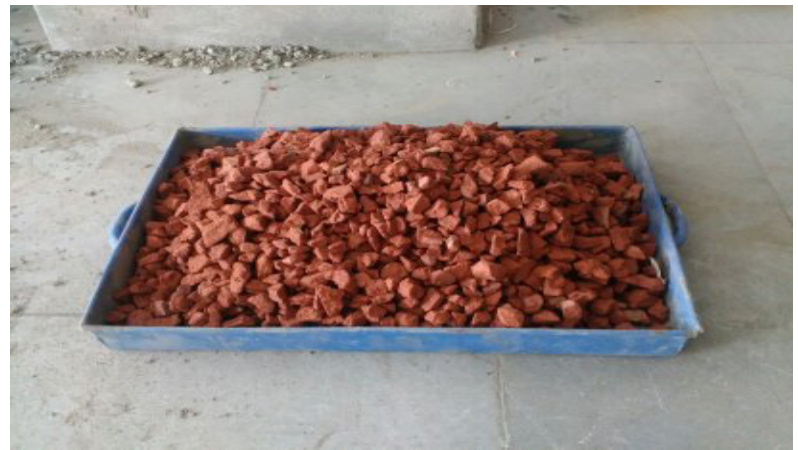

Fig. 2: Brick Ballast
Optimum Percentage of Sawdust and Brick Ballast in Light Weight Concrete

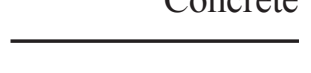


Singla, N.

Kumar, M.

Table 1: Detail of Test Specimens

\begin{tabular}{|c|c|c|c|}
\hline Sr. No. & $\begin{array}{c}\text { Designation of } \\
\text { Casting Batch }\end{array}$ & $\begin{array}{c}\text { \% Replacement of } \\
\text { Sand with Sawdust }\end{array}$ & $\begin{array}{c}\text { \% Replacement of } \\
\text { Gravels with Brick } \\
\text { ballast }\end{array}$ \\
\hline 1 & S 0 & - & - \\
\hline 2 & S 1 & 4 & 8 \\
\hline 3 & S2 & 4 & 16 \\
\hline 4 & S 3 & 4 & 24 \\
\hline 5 & S 4 & 8 & 8 \\
\hline 6 & S 5 & 8 & 16 \\
\hline 7 & S6 & 8 & 24 \\
\hline 8 & S 7 & 12 & 8 \\
\hline 9 & S 8 & 12 & 24 \\
\hline 10 & S 9 & 12 & 16 \\
\hline
\end{tabular}

\section{RESULT AND DISCUSSION}

Slump cone test: - Slump cone test is used to check the workability of concrete. A constant water cement ratio of 0.42 is used throughout the research work. Additional water reducing admixture is used to increase the workability of concrete.

Table 2 shows the slump values of concrete mix at defined replacement. Graphical representation of the slump test values illustrated in Fig. 3. Facts revealed that the slump value decreases with increases in the quantity of sawdust and brick ballast aggregates.

Table 2: Slump values

\begin{tabular}{|c|c|c|}
\hline Sr. No. & Designation of Specimen & Slump Value(mm) \\
\hline 1 & S0 & 58 \\
\hline 2 & S1 & 49 \\
\hline 3 & S2 & 41 \\
\hline 4 & S3 & 36 \\
\hline 5 & S4 & 44 \\
\hline 6 & S5 & 38 \\
\hline 7 & S6 & 31 \\
\hline 8 & S7 & 36 \\
\hline 9 & S & 24 \\
\hline 10 & S9 & 11 \\
\hline
\end{tabular}




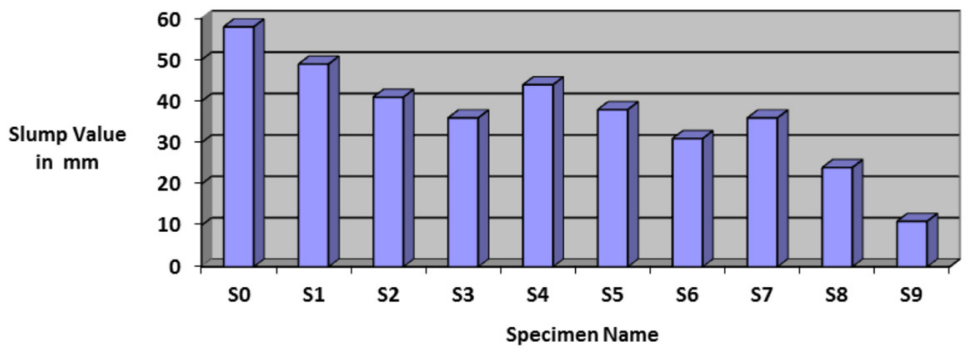

Optimum

Percentage of Sawdust and Brick Ballast in Light Weight Concrete

Fig. 3: Graphical representation of Slump Value

Compacting Factor Test: - The compacting factor test is used to check the workability of concrete. From this research work, it is investigated that with increase in the replacement proportion of sawdust and brick ballast in concrete, the compacting factor value decreases.

Table 3: Compaction factor values

\begin{tabular}{|c|c|c|}
\hline S. No. & Designation of Specimen & Compaction Factor Value \\
\hline 1. & $\mathrm{~S} 0$ & 0.915 \\
\hline 2. & $\mathrm{~S} 1$ & 0.86 \\
\hline 3. & $\mathrm{~S} 2$ & 0.81 \\
\hline 4. & $\mathrm{~S} 3$ & 0.785 \\
\hline 5. & $\mathrm{~S} 4$ & 0.83 \\
\hline 6. & $\mathrm{~S} 5$ & 0.75 \\
\hline 7. & $\mathrm{~S} 6$ & 0.71 \\
\hline 8. & $\mathrm{~S} 7$ & 0.80 \\
\hline 9. & $\mathrm{~S} 8$ & 0.72 \\
\hline 10. & $\mathrm{~S} 9$ & 0.67 \\
\hline
\end{tabular}

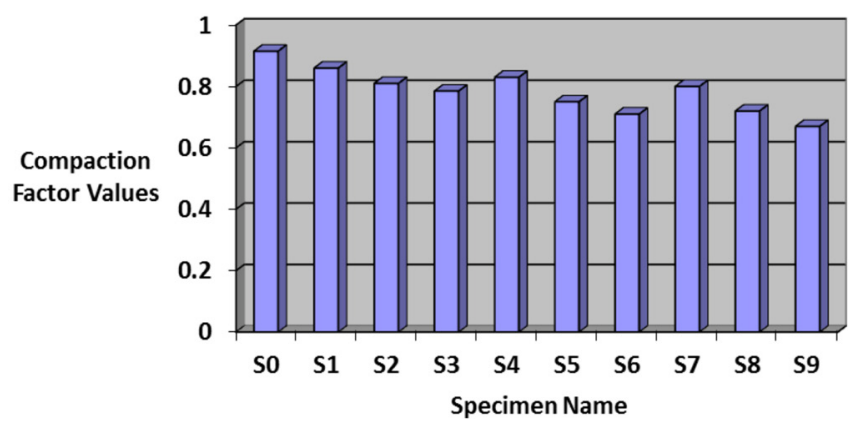

Fig. 4: Graphical representation of Compaction Factor Values

Compressive strength: - The compressive strength gradually decreases for the increasing replacement percentage of sawdust and brick ballast aggregates. 
Singla, N.

Kumar, M.
For mix S0 (Control Mix), the characteristics compressive strength after 28 days is $43.80 \mathrm{~N} / \mathrm{sq}$. mm for M 30 grade of concrete.

Table 4: Compressive strength of various Mix proportion at 28 days

\begin{tabular}{|c|c|c|c|c|c|}
\hline \multirow{2}{*}{$\begin{array}{l}\text { S. } \\
\text { No. }\end{array}$} & \multirow{2}{*}{$\begin{array}{l}\text { Designation } \\
\text { of Mix }\end{array}$} & \multirow{2}{*}{$\begin{array}{l}\text { Specimen } \\
\text { Name }\end{array}$} & \multicolumn{3}{|c|}{$\begin{array}{c}\text { Compressive Strength of Specimen } \\
\text { (After } 28 \text { days) }\end{array}$} \\
\hline & & & $\begin{array}{l}\text { Load } \\
(\mathrm{KN})\end{array}$ & $\begin{array}{c}\text { Compressive } \\
\text { Strength (N/sq. mm) }\end{array}$ & $\begin{array}{l}\text { Mean Compressive } \\
\text { Strength (N/sq. mm) }\end{array}$ \\
\hline \multirow[t]{3}{*}{1.} & \multirow[t]{3}{*}{ S0 } & 1 & 990 & 44.00 & \multirow{3}{*}{43.85} \\
\hline & & 2 & 998 & 44.35 & \\
\hline & & 3 & 972 & 43.20 & \\
\hline \multirow[t]{3}{*}{2.} & \multirow[t]{3}{*}{ S1 } & 1 & 868 & 38.57 & \multirow{3}{*}{38.17} \\
\hline & & 2 & 858 & 38.13 & \\
\hline & & 3 & 851 & 37.82 & \\
\hline \multirow[t]{3}{*}{3.} & \multirow[t]{3}{*}{ S2 } & 1 & 790 & 35.11 & \multirow{3}{*}{34.50} \\
\hline & & 2 & 777 & 34.53 & \\
\hline & & 3 & 762 & 33.86 & \\
\hline \multirow[t]{3}{*}{4.} & \multirow[t]{3}{*}{ S3 } & 1 & 765 & 34.00 & \multirow{3}{*}{32.13} \\
\hline & & 2 & 718 & 31.91 & \\
\hline & & 3 & 686 & 30.48 & \\
\hline \multirow[t]{3}{*}{5.} & \multirow[t]{3}{*}{ S4 } & 1 & 785 & 34.88 & \multirow{3}{*}{34.07} \\
\hline & & 2 & 770 & 34.22 & \\
\hline & & 3 & 745 & 33.11 & \\
\hline \multirow[t]{3}{*}{6.} & \multirow[t]{3}{*}{ S5 } & 1 & 747 & 33.20 & \multirow{3}{*}{31.95} \\
\hline & & 2 & 708 & 31.46 & \\
\hline & & 3 & 702 & 31.20 & \\
\hline \multirow[t]{3}{*}{7.} & \multirow[t]{3}{*}{ S6 } & 1 & 598 & 26.57 & \multirow{3}{*}{25.40} \\
\hline & & 2 & 565 & 25.11 & \\
\hline & & 3 & 552 & 24.53 & \\
\hline \multirow[t]{3}{*}{8.} & \multirow[t]{3}{*}{ S7 } & 1. & 710 & 31.55 & \multirow{3}{*}{29.14} \\
\hline & & 2 & 637 & 28.31 & \\
\hline & & 3 & 620 & 27.55 & \\
\hline \multirow[t]{3}{*}{9.} & \multirow[t]{3}{*}{ S8 } & 1 & 615 & 27.33 & \\
\hline & & 2 & 532 & 23.64 & 24.44 \\
\hline & & 3 & 503 & 22.35 & \\
\hline 10 & S9 & 1 & 470 & 20.88 & \\
\hline & & 2 & 456 & 20.26 & 20.08 \\
\hline & & 3 & 430 & 19.11 & \\
\hline
\end{tabular}




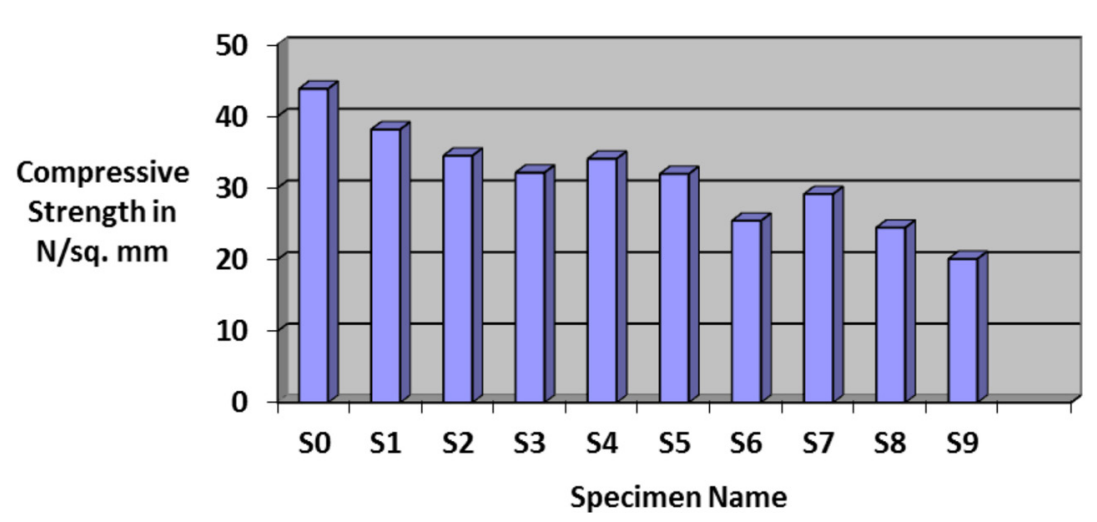

Optimum

Percentage of

Sawdust and

Brick Ballast in

Light Weight

Concrete

Fig. 5: Graphical representation of Compressive Strength

Weight Reduction:- The weight of concrete cubes is recorded for calculating weight reduction properties of sawdust and brick ballast aggregates concrete. Table 5 shows the weight reduction obtained for various mixes in percentages. The graphical representation is shown in the Fig. 6 It is evident from the graph that weight of the concrete cubes decreases with increase in the replacement proportion of sawdust and brick ballast aggregates.

Table 5: Weight reduction of Concrete of Various mix proportions

\begin{tabular}{|c|c|c|c|c|c|c|}
\hline Sr. & \multirow{2}{*}{$\begin{array}{c}\text { Mix } \\
\text { designation }\end{array}$} & \multicolumn{3}{|c|}{ Weight of specimen } & \multirow{2}{*}{$\begin{array}{c}\text { Mean } \\
\text { Value } \\
\text { (After 28 days in Kg) }\end{array}$} & $\begin{array}{c}\text { \% Reduction in } \\
\text { (Kg) }\end{array}$ \\
\cline { 2 - 5 } & & I & II & III & (\%) \\
\hline 1. & S0 & 8.3 & 8.4 & 8.4 & 8.36 & 0 \\
\hline 2. & S1 & 7.8 & 7.9 & 7.8 & 7.83 & 6.33 \\
\hline 3. & S2 & 7.7 & 7.9 & 7.7 & 7.76 & 7.17 \\
\hline 4. & S3 & 7.4 & 7.7 & 7.5 & 7.53 & 9.92 \\
\hline 5. & S4 & 7.5 & 7.7 & 7.7 & 7.63 & 8.73 \\
\hline 6. & S5 & 7.3 & 7.6 & 7.5 & 7.46 & 10.68 \\
\hline 7. & S6 & 7.2 & 7.3 & 7.3 & 7.26 & 13.15 \\
\hline 8. & S7 & 7.6 & 7.4 & 7.6 & 7.53 & 9.88 \\
\hline 9. & S8 & 7.3 & 7.4 & 7.5 & 7.4 & 11.48 \\
\hline 10. & S9 & 7.0 & 7.2 & 7.2 & 7.13 & 14.67 \\
\hline
\end{tabular}


Singla, N.

Kumar, M.

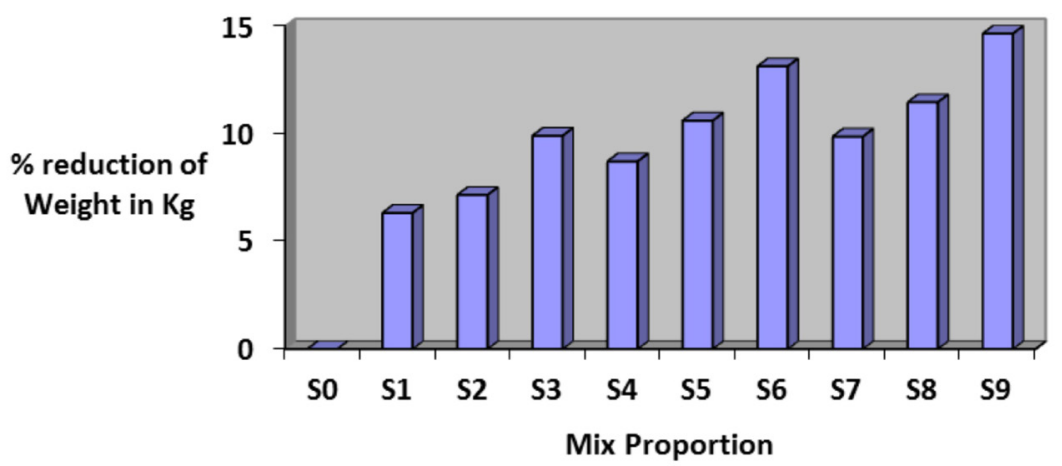

Fig. 6: Graphical representation of \% reduction of Weight

On the basis of the results of Compressive strength and \% weight reduction, we found S5 is the optimum mix. Cost analysis between S0 (Controlled Mix) and S5 (Optimum Mix) has also been done.

Cost Analysis: - Table 6 shows the Cost analysis for M30 grade of optimum mix concrete which is replacement of $8 \%$ sawdust and $16 \%$ brick ballast.

Table 6: Cost Analysis

\begin{tabular}{|c|c|c|c|c|c|c|}
\hline \multirow{2}{*}{$\begin{array}{l}\text { Sr. } \\
\text { No. }\end{array}$} & \multirow{2}{*}{$\begin{array}{l}\text { Materials } \\
\text { Required }\end{array}$} & \multirow{2}{*}{$\begin{array}{c}\text { Cost/ } \\
\mathrm{Kg}\end{array}$} & \multicolumn{2}{|c|}{ Quantity in $\mathrm{Kg} / \mathrm{cu} . \mathrm{m}$} & \multicolumn{2}{|c|}{$\begin{array}{c}\text { Cost of Concrete in Rs./ cu. } \\
\text { M }\end{array}$} \\
\hline & & & $\begin{array}{l}\text { Controlled } \\
\text { Mix }\end{array}$ & $\begin{array}{l}\text { Sawdust and } \\
\text { Brick Ballast }\end{array}$ & $\begin{array}{l}\text { Controlled } \\
\text { Mix Con- } \\
\text { crete }\end{array}$ & $\begin{array}{l}\text { Sawdust and } \\
\text { Brick Ballast }\end{array}$ \\
\hline 1. & Cement & $6.80 /-$ & $465 /-$ & $465 /-$ & $3167 /-$ & $3167 /-$ \\
\hline 2. & River Sand & $0.50 /-$ & $636 /-$ & $585 /-$ & $318 /-$ & $292.5 /-$ \\
\hline 3. & Sawdust & $0.80 /-$ & - & $5.45 /-$ & - & $3.27 /-$ \\
\hline 4. & $\begin{array}{l}\text { Coarse Aggre- } \\
\text { gate(Gravels) }\end{array}$ & $0.60 /-$ & $1391 /-$ & $1168 /-$ & $834 /-$ & $700.8 /-$ \\
\hline 5. & Brick Ballast & $0.57 /-$ & - & $154 /-$ & - & $88.36 /-$ \\
\hline \multicolumn{5}{|c|}{ Grand Total } & $4319 /-$ & $4251 /-$ \\
\hline
\end{tabular}

The cost is reduced up to Rs. 68 per cubic meter of concrete. This is $1.55 \%$ reduction of the total cost per cubic meter of concrete. This will increase when the lead distance for the river sand increases and also where the saw dust is abundantly available such as in tropical areas where the cost of sawdust is very less.

\section{CONCLUSIONS}

The following conclusions have been found from the present work:-

1) 28 days compressive strength of the concrete decreases gradually with 
increasing the replacement percentages. For the optimum mix S5 (8 SD 16 $\mathrm{BB})$, the compressive strength of M 30 grade of concrete decreases from $43.85 \mathrm{~N} / \mathrm{sq}$. mm (For Controlled Mix) to $31.94 \mathrm{~N} / \mathrm{sq} . \mathrm{mm}$.

2) For the optimum mix S5, the weight reduction up to $10.68 \%$ and $1.55 \%$ reduction in production cost per cubic meter of concrete.

3) As the replacement proportion of sawdust and brick ballast increases in concrete then slump value of the mixes gradually decreases and workability also decreases. At the optimum replacement proportion i.e. S5 (8 SD 16 BB), the slump value decreases from $58 \mathrm{~mm}$ (For Controlled Mix) to $40 \mathrm{~mm}$.

4) As the replacement proportion of sawdust and brick ballast increases in concrete then compacting factor value of the mixes gradually decreases and workability is also decreases. At the optimum replacement proportion i.e. S5 (8 SD $16 \mathrm{BB}$ ), the compacting factor value decreases from 0.915 (For Conventional concrete) to 0.75 .

5) This sawdust and brick ballast concrete can be used in the production of non load bearing precast concrete units, flooring and pavement concrete, hollow blocks and flooring tiles.

\section{REFRENCES}

1) K. Ambiga and P. Meenakshi (2015), "Studies on Strength of concrete by Partial Replacement of sand with Sawdust", International Journal of Advanced Engineering Research and Studies.

2) Sourabh G. Sable and S.B. Walke (2015), "Experimental Investigation on Properties of Concrete for Partial replacement of Brick Ballast Aggregate", International Journal of Emerging Technology and advanced Engineering.

3) P. Sri Chandana and Shaik Ahamad Myauddin (2015), "Experimental study on strength of concrete by partial replacement of Fine aggregate with Sawdust and Robosand", International Journal and Magazine of Engineering, Technology, Management and Research.

4) K. Gopinath, K. Anuratha, R. Harisundar and M. Saravanan (2015), "Utilization of Sawdust in Cement Mortar and Cement Concrete", International Journal of Scientific Research, Volume 6, Issue 8, August 2015.

5) Mahumud Abubakar and Abayomi Afolayan (2013), "Partial replacement of Sand with Sawdust in Concrete Production", Conference Paper, May 2013.

6) Prof. R. Sathish Kumar (2012), "Experimental study on the properties of concrete made with alternate construction materials", International Journal of Modern Engineering Research, Vol. 2, Issue 5, Sept-Oct. 2012.

7) M. Mageswari and B. Vidivelli (2009), "The use of sawdust ash as fine aggregate replacement in Concrete", Journal of Environmental Research and Development, Vol.3, No. 3, January-March 2009.

8) Gambhir, ML. (1986), Concrete Technology, Tata McGraw-Hill Publishing Company Limited, New Delhi.

9) Gambhir, ML (1992) Concrete Manual, $4^{\text {Th }}$ ed, Dhanpat Rai and Sons, Delhi.

10) IS: 10262-2009; Concrete Mix Proportioning -Guidelines.

11) IS: 456-2000; Code of Practice for Plain and Reinforced Concrete.
Optimum

Percentage of

Sawdust and

Brick Ballast in

Light Weight

Concrete 
Singla, N.

Kumar, M.
12) IS: 516-1956; Methods of Tests for strength of concrete.

13) IS: 1199-1959; Methods of sampling and analysis of concrete.

14) IS: 1489-1991;- Portland Pozzolona Cement -Specifications.

15) IS: 383-1970; Specifications for Coarse and fine aggregates from natural sources for concrete. 